\title{
Socially Sustainable Supply Chain Management and Suppliers' Social Performance: The Role of Social Capital
}

\author{
Mohammad Alghababsheh* \\ Department of Business Management \\ School of Business \\ Mutah University \\ Alkarak \\ 61710 \\ Jordan \\ m.alghababsheh@mutah.edu.jo
}

\author{
David Gallear \\ Brunel Business School \\ Brunel University London \\ Uxbridge \\ UB8 3PH \\ United Kingdom \\ david.gallear@brunel.ac.uk
}




\title{
Socially Sustainable Supply Chain Management and Suppliers' Social Performance: The Role of Social Capital
}

\begin{abstract}
The implementation of socially sustainable supply chain management (SSCM) practices (i.e., assessment and collaboration) to tackle suppliers' social deficiencies (e.g., the use of child labour) often requires a level of cooperation that can be difficult to establish. Despite this daunting challenge, scant scholarly attention has been paid to exploring how the implementation of socially SSCM practices can be effectively facilitated and enhanced. Drawing on social capital theory, this study examines the individual impact of assessment and collaboration practices on suppliers' social performance and explores whether and how these effects can be moderated (strengthened) by the level of social capital (i.e., relational, cognitive, and structural) embedded in the buyer-supplier relationship. Based on a survey of 119 manufacturing companies in the UK we found that assessment practices are less likely to influence suppliers to improve social performance compared to collaboration practices. However, when relational and structural capital are manifested in the relationship, assessment practices become significant in driving suppliers' social performance. We also found that the positive impact of collaboration practices is more pronounced when relational and cognitive capital are established in the relationship. This paper contributes to the growing socially SSCM literature by disentangling the vital and relative importance of social capital dimensions on the implementation of socially SSCM practices.
\end{abstract}

Keywords: Responsible; Social Capital; Social Performance; Supplier; Supply Chain; Sustainable.

\section{Introduction}

To deal with fiercely competitive business environments organizations very often seek to focus on their core competencies and achieve considerable cost savings by outsourcing some of their products and services to suppliers (Klassen and Vereecke 2012). To meet increasing buying firms' demands for better business deals involving cost reduction, higher order flexibility, and shorter lead time, under pressure suppliers, particularly those benefiting from weak regulatory environments, often turn to unethical actions some of which can amount to modern slavery practices, such as child labour, forced labour, and health and safety issues (Alghababsheh et al. 2018; Mani et al. 2016; Carne 2013). A recent report of the International Labour Organization (ILO) released in 2017 revealed shocking figures of 152 million people in child labour and 24.9 in forced labour across the world (ILO 2017). The collapse of Rana Plaza building in Bangladesh which housed five ready-made garment factories producing 
clothes for major western brands (such as Primark and Benetton) (ILO 2018) in 2013, killing 1,132 people and injuring more than 2,500, has also highlighted the size of the danger and hazards facing workers from suppliers' unethical actions (e.g., lack of health and safety and poor working conditions).

Triggered by the potentially damaging impact of mass criticisms from powerful stakeholders on their reputation, as well as the likelihood of disruption in the supply process from suppliers due to work accidents, buying firms have begun to integrate ethical sourcing thinking into supply chain strategy thereby adopting alternative routes for tackling unethical actions of suppliers (Huq et al. 2014; Mani and Gunasekaran 2018).The current socially SSCM research suggests that some buying firms will pursue a 'hands-off' route in which they immediately switch from an existing violating supplier without warning ("zero-tolerance") to select an alternative more responsible and credible supplier (Porteous et al. 2015). However, unfavourable cost-benefit analyses of this route (e.g., increased search costs and possible supply disruption) has shifted buying firms' behaviour towards a 'hands-on' route in which firms allocate resources and time to drive and build the social sustainability of existing suppliers (Klassen and Vereecke 2012; Yadlapalli et al. 2018). Following this route, buying firms can adopt two approaches comprising different practices, namely the 'assessment' approach and the 'collaboration' approach. In the assessment approach, the assumption is that suppliers' social misconducts represent form of opportunistic behaviour and therefore monitoring and auditing suppliers' operations are drivers of social performance (Sancha et al. 2015). In the collaborative approach, establishing development programmes, dedicating 'sustainability-specific' investments, and conducting joint meeting are identified as effective mechanisms to build suppliers' capabilities and improve social performance (Alghababsheh et al. 2018; Huq et al. 2016).

Recent research advances on socially SSCM have revealed that the successful implementation of assessment and collaboration practices, and hence tackling supplier's social failures, often requires a level of cooperation between buyer and supplier that can be difficult to establish (e.g., Alghababsheh et al. 2018; Lund-Thomsen and Lindgreen 2014). This cooperation on socially SSCM between buyer and supplier requires mutual exchange of information and knowledge, the allocation of a variety of resources (e.g., financial and human capital), and very importantly commitment, which can be challenging to establish due to uncertainty, cultural differences, and the fear of opportunistic behaviours in the relationship (Klassen and Vereecke 2012; Mani et al. 2018; Yadlapalli et al. 2018). Despite these challenges, scant scholarly attention has been paid to exploring how to facilitate and increase the effectiveness of the implementation of socially SSCM practices to tackle supplier's social misconduct. 
Emerging research in the supply chain management domain has demonstrated the value that can be accured to the buyer-supplier relationship from social resources developed and embedded in relationship (e.g., Blonska et al. 2013; Dubey et al. 2018; Krause et al. 2007; Lawson et al. 2008; Whipple et al. 2015). In particular, social capital - the actual and potential resources embedded within, available through and derived from the buyer-supplier relationship - has been highlighted as a significant resource that facilitates collective actions (Adler and Kwon 2002; Nahapiet and Ghoshal 1998). Specifically, social capital in its different forms including relational, cognitive, and structural are purported to enhance a variety of aspects in the buyer-supplier relationships, including information sharing (Li et al. 2014), learning (Kohtamäki and Bourlakis 2012), resilience (Johnson et al. 2013), and more importantly reducing opportunism (Lioliou and Zimmermann 2015; Wang et al. 2013), all of which can be key aspects for supporting the successful implementation of assessment and collaboration practices. Yet, this significant role of social capital dimensions in facilitating the implementation of socially SSCM practices has been largely ignored in the socially SSCM literature (Rodriguez et al. 2016; Zhang et al. 2017). This study aims to fill this gap by theorising and empirically examining the moderating effects of social capital dimensions (i.e., relational, cognitive, and structural) on the relationship between socially SSCM practices (i.e., assessment and collaboration) and suppliers' social performance based on the buyers' perception. In doing so, the study addresses the following questions:

RQ1. How do buyers perceive the effects of assessment and collaboration practices on suppliers' social performance?

RQ2. What role does social capital (i.e. relational, cognitive, and structural) embedded in the buyer-supplier relationship play in facilitating the implementation of assessment and collaboration practices?

Based on a mail survey of 119 stratified randomly selected large manufacturing companies in the UK, we examine the buyers' perception of the effects of assessment and collaboration practices on suppliers' social performance and explore whether and how these effects can be moderated (strengthened) by the level of social capital (i.e., relational, cognitive, and structural) embedded in the buyer-supplier relationship. Accordingly, this study contributes to the current literature on SSCM and the broader literature on inter-organizational social capital in three important ways. Firstly, this study exclusively examines the social dimension of sustainability in the context of supply chain management. This adds necessary balance to the literature which has mainly focused on the environmental side of sustainability and provides a clearer and deeper understanding of the effect of socially SSCM practices on suppliers' social performance. This is in contrast to the majority of the previous studies 
which have combined the environmental and social dimension into single construct, thereby making separate analysis and more discriminating interpretation impossible. Secondly, the study theoretically proposes and empirically examines the moderating effect of social capital dimensions on the relationship between socially SSCM practices (i.e., assessment and collaboration) and suppliers' social performance. This advances the current knowledge by exploring how social capital as a relational aspect can underpin and facilitate an effective implementation of assessment and collaboration practices. Finally, this study explores the role of all social capital dimensions simultaneously on the implementation of different socially SSCM practices. This nuanced investigation extends prior research on social capital in the buyer-supplier relationship which has predominantly focused on examining the impact of specific social capital dimensions on traditional relationship outcomes (e.g., performance). It does so by disentangling the unique role and relative importance of each of the three prominent dimensions of social capital on the implementation of socially SSCM.

The paper is structured as follows. In the next section, theoretical background on socially SSCM practices and social capital is provided before our hypotheses are developed in section 3. Following this, we present our methodology (section 4). We report and discuss our results in sections 5 and 6 , respectively. We then draw our conclusions and outline implications for theory and practice in section 7. Finally, we highlight limitations of the work and suggest directions for future research.

\section{Theoretical background}

\subsection{Socially SSCM practices}

Socially sustainable supply chain management (SSCM) practices can be broadly defined as the mechanisms, practices, methods, and activities by which buying firms influence suppliers' actions and capabilities to meet social objectives (Klassen and Vereecke 2012; Yawar and Seuring 2018). Our understanding of the nature of socially SSCM practices is guided by two dominant theoretical perspectives - transaction cost economics (TCE) (Williamson 1975) and the Relational View (RV) (Dyer and Singh 1998). Previous socially SSCM research drawing primarily on TCE has suggested that to mitigate suppliers' social issues assessment practices (e.g., auditing) should be in place (e.g., Jiang 2009; Sancha et al. 2016). At the same time, parallel literature grounded in the RV has called for reinforcing collaboration practices (e.g., supplier development) to build suppliers' capabilities and subsequently drive their social performance (e.g., Huq et al. 2016; Sancha et al. 2015). Thus, socially SSCM practices can be classified into two distinct sets of practices: assessment practices and collaboration practices. 
Supplier assessment practices refer to the practices by which a buyer guides, assesses, monitors, and controls suppliers' internal actions regarding working hours and conditions, health and safety, employees' welfare, and the avoidance of the use of child labour (Huq et al. 2016; Sancha et al. 2016). In this context, companies often establish and introduce a aode of conduct as a frame of reference providing written baseline expectations and standards of acceptable behaviours from suppliers (Andersen and Skjoett-Larsen 2009). To increase transparency, companies also demand that suppliers obtain well-recognised certifications (e.g., SA8000) developed and granted by high profile independent bodies ( $\mathrm{Ni}$ and Sun 2018). Through auditing, companies evaluate the extent of suppliers' adherence to the guidelines codified in codes of conduct and other third-party certifications and standards (Huq and Stevenson 2018). Auditing refers to 'the procedures through which internal or external auditors systematically check whether a supplier is complying with the requirements contained in a given code of conduct (Lund-Thomsen 2008; p. 1013). Thus, the process can be internally accomplished by asking suppliers to perform an audit of their own operations or using an independent third-party auditor (Huq et al. 2016). However, recent disasters (e.g., the Rana Plaza collapse) and field evidence has revealed that despite being audited, suppliers often falsify compliance and/or pay bribes to pass domestic third-party auditing processes (Huq et al. 2014; Jiang 2009). This has, in turn, led many buyers to carry out the auditing process using their own trained auditors (Huq et al. 2016). The auditing process involves a physical inspection of the supplier's facilities, operations, records, and documents (e.g., timesheets), as well as conducting interviews with workers (Ciliberti et al. 2008).

Supplier collaboration practices refer to those practices by which buyers work closely with suppliers to build their capabilities in order to effectively improve performance (Klassen and Vereecke 2012; Rodriguez et al. 2016). Through collaboration practices, buyers seek to improve business operations or product designs that do not only promote the welfare of workers and ensure a safer workplace environment but also create opportunities for providing innovative sustainable offerings to the market that can lead to sustained competitive advantage (Huq and Stevenson 2018; Klassen and Vereecke 2012; Ni and Sun 2018). To achieve this, buying firms use a variety of practices and tools that require different levels of involvement and investment (Alghababsheh 2018, Zhang et al. 2017). For example, buying firms can set up supplier development and education programmes in which they provide technical, technological, and managerial training for the suppliers' personnel either at their facility or at those of the suppliers (Yadlapalli et al. 2018; Yawar and Seuring 2018; Zhang et al. 2017). Some commonly implemented collaboration practices also involve establishing mutual interaction routines to share know-how, allocating 'sustainability-specific' investments, organising joint meetings, and awarding suppliers subsidies to obtain third-party certification (Jiang 2009; Klassen and Vereecke 
2012; Marshall et al. 2017; Porteous et al. 2015; Sancha et al. 2015). Thus, creating a two-way dialogue and emphasising a long-term cooperative relationship between buyer and supplier are the main features of the collaboration approach (Alghababsheh et al., 2018).

\subsection{Social capital}

The core tenant of social capital theory is that individuals' or organizations' networks of relationships are considered to be valuable resources that facilitate collective actions (Adler and Kwon 2002; Inkpen and Tsang 2005). Two main views have emerged on the source of social capital value in the relationship, namely the structural and relational view (Kostova and Roth 2003). Based on social network theory, the structural view argues that it is the structure of the relationship that provides value for individuals (e.g., Baker 1990). On the other hand, the relational view contends that it is the nature (i.e., content) of the relationship within the structure that generates value for individuals (Kostova and Roth 2003). Integrating these two perspectives, Nahapiet and Ghoshal (1998, p. 243) defined social capital as "the sum of the actual and potential resources embedded within, available through and derived from the network of relationships possessed by an individual or social unit". Under this conceptualisation, Nahapiet and Ghoshal (1998) proposed that social capital is a tripartite concept consisting of relational, cognitive, and structural capital.

Relational capital refers to the goodwill that exists between buyer and supplier and leveraged through a history of repeated interactions (Burt 1997). Relational capital is a multi-facetted concept including trust, obligation, respect, and friendship that present in the relationship between buyer and supplier (Kale et al. 2000; Nahapiet and Ghoshal 1998). Cognitive capital portrays those resources providing shared representations, interpretations, perceptions, and systems of meaning in the relationship (Nahapiet and Ghoshal 1998). Cognitive capital manifests when buyer and supplier have shared language and codes (Nahapiet and Ghoshal 1998) and aligned culture, business philosophy, goals and vision (Villena et al. 2011). Structural capital refers to the overall pattern of connections between buyer and supplier (Nahapiet and Ghoshal 1998). Structural capital reflects the presence, frequency, and strength of social interactions between buyer and supplier (Tsai and Ghoshal 1998). Social interactions represent the social processes and activities that are conducted between buyer and supplier to coordinate and structurally embed the relationship (Roden and Lawson 2014).

\section{Hypotheses development}

Our conceptual model establishes a relationship between socially SSCM practices (i.e., assessment and collaboration), social capital dimensions (i.e., relational, cognitive, and structural), and suppliers' social performance (see Figure 1). The model suggests that assessment and collaboration practices 
are both individually positively related to suppliers' social performance. However, the positive impacts of assessment and collaboration practices on suppliers' social performance can be magnified by a higher level of social capital embedded in the buyer-supplier relationship. Specifically, the model posits that social capital dimensions positively moderates the relationship between socially SSCM practices and suppliers' social performance.

Insert Figure (1) here

\subsection{Socially SSCM practices and suppliers' social performance}

The study's prediction of the positive impact of the assessment practices on suppliers' social performance is consistent with the reasoning of TCE theory. Based on TCE, firms craft contracts and establish monitoring in order to reduce opportunism and ensure compliance with agreements (Grover and Malhotra 2003). In inter-organizational relationships, opportunism refers to "the act or behaviour performed by one party to seek its unilateral gains at the expense of the other by breaking implicit or explicit contracts, abusing power, withholding or distorting information, withdrawing commitments or promises, shirking obligations, or grafting joint earnings" (Luo et al. 2015, p. 609). Recent research has shown that suppliers may increasingly transfer the continual cost pressure from buyers to workers by eroding workers' welfare, reducing investments in working conditions improvement and employing children in their facilities (Awaysheh and Klassen 2010; Jiang 2009; Sancha et al. 2016). These violations of the social obligations and expectations specified by buyers represent forms of suppliers' opportunistic behaviour (Huq et al. 2014; Sancha et al. 2016). However, buyers can employ different monitoring and assessment practices to prevent suppliers from behaving opportunistically. It is reasonable to argue therefore that since the assessment practices reflect heavy monitoring and contract specifications (i.e., code of conduct), they would lead to less violation and thus improved suppliers' social performance.

It is important to note that the current literature exhibits two streams of empirical research that come to opposite conclusions regarding the impact of assessment practices on suppliers' social performance. One stream holds that the use of assessment practices does not lead to improving suppliers' social performance, while the other and more recent stream suggests that the use of assessment practices can improve enhance social performance. For example, Jiang (2009) revealed that adopting auditing and monitoring as governance did not lead to supplier compliance to codes of conduct in the context of the apparel and textile industry. Similarly, Huq et al. (2014) observed from their field visits to suppliers' factories in Bangladesh that buyers' requirements (e.g., certification) and 
enforcement of a code of conduct drive suppliers to hide workplace violations and pursue instead 'mock' compliance, due in part to the lack of financial support for small suppliers from buyers to obtain and implement these requirements. Likewise, Sancha et al. (2016) found that buyers' assessment and monitoring activities of current working conditions and other social issues in suppliers' premises did not effectively reduce and tackle these issues, arguing that such activities only capture a single 'snapshot' of the current situation with no dedicated continuous follow-ups. However, taking the suppliers' perspective, Lee (2016) found that responsible supply chain social practices (i.e., auditing and codes of conduct) did lead to improved social performance from suppliers. This was recently echoed by Zhang et al.'s (2017) study which it revealed that using standard operating procedures and auditing (as indirect supplier development practices) did improve supplier social responsibility in the pharmaceutical industry. Despite these conflicting prior findings, in this study we followed the logic of the TCE argument proposed above, and therefore:

\section{H1a: Assessment practices are positively associated with suppliers' social performance.}

Our argument for the positive impact of collaboration practices on suppliers' social performance is in line with the logic of the Relational View (RV). The RV provides an alternative explanation to the existing models (i.e., industry structure and resource-based views) of the source of a firm's competitive advantage. While the industry structure view explains a firm's abnormal performance in an industry with specific structural attributes (Porter 1980), and the resource-based view (Barney 1991) explains firm's superior returns with resources heterogeneity, the RV contends that idiosyncratic inter-organizational linkages are a source of relational rents (Dyer and Singh 1998). The $\mathrm{RV}$ argues that superior performance can be jointly generated in an inter-organizational relationship, if partners commit relationship-specific assets, establish knowledge sharing routines, and provide complementary resources/capabilities (Dyer and Singh 1998). The collaboration practices represent interaction routines established between buyer and supplier that foster mutual learning, resource sharing, and knowledge exchange, enabling suppliers to build specific capabilities to improve their social performance (Gualandris and Kalchschmidt 2016). Therefore, it reasonable to argue that the collaboration practices can lead to increase an suppliers' social performance as a result of their dedicated inter-organisational collaboration.

The current literature provides empirical support for the effectiveness of the collaboration approach to enhance the social responsibility of suppliers. Sancha et al. (2015) argue that the collaboration approach facilitates more observable progress in suppliers' working environments because when buyers and suppliers work closely together on social issues, they develop the specific capabilities and resources in the long-term to tackle these issues. By establishing training and education sessions as 
collaborative practice, buyers can enhance suppliers' current understandings of social sustainability and its positive implications on their operations, productivity, and market attractiveness, which in turn motivates them towards socially responsible actions in their factories (Huq et al. 2014; Yadlapalli et al. 2018). In addition to increasing suppliers' awareness, the collaboration practices serve as interaction routines that foster the exchange of assets and resources towards tangible and effective improvement of social performance throughout the supply chain (Gualandris and Kalchschmidt 2016). Supplier social sustainability development promotes mutual learning and knowledge exchange, enabling and supporting suppliers to develop the necessary capabilities to improve work infrastructure, health and safety procedures, and labour conditions (Huq et al. 2016; Sancha et al. 2015). The collaboration between buyer and supplier can also lead to the development of suppliers' manufacturing processes that not only helps to ensure safer products for customers but also a safer working environment for workers (Huq et al. 2016; Marshall et al. 2017). Therefore, we propose the following:

H1b: Collaboration practices are positively associated with suppliers' social performance.

\subsection{The moderating role of social capital}

\subsubsection{The moderating role of relational capital}

Assessment practices involve measuring and monitoring suppliers' performance, which requires continuous exchange of information and relevant inputs from both buyer and supplier (Grosvold et al. 2014; Sancha et al. 2016). Building relational capital not only fosters the exchange and transfer of information (Kale et al. 2000; Lee and Ha 2018), but can also increase the accuracy, adequacy, and credibility of the exchanged information (Li et al. 2014). Likewise, trust and shared expectations can ensure rapid and timely access to information and resources (Adler and Kwon 2002; Johnson et al. 2013). Relational capital reduces uncertainty in the relationship (Lioliou and Zimmermann 2015; Poppo and Zenger 2002), which leads to a more efficient performance evaluation process for relationships with partners (Wuyts and Geyskens 2005). Developing trust makes parties more inclined to openly communicate and display transparent practices (Kale et al. 2000; Villena et al. 2011), which in turn can reduce the likelihood of opportunistic acts (Cilibteri et al. 2009). Moreover, relational capital enables joint sense-making between supply chain partners, which can develop a shared understanding and fit between their expectations and requirements (Huikkola et al. 2013). The continuity and cooperation encouraged by the trust may generate contractual enhancements that pave the way for even more cooperation (Poppo and Zenger 2002) and reduces coordination costs (Nahapiet and Ghoshal 1998). Transaction costs and opportunism are at a minimum when trust and 
relational norms operate in conjunction with formal governance (Liu et al. 2009; Gulati and Nickerson 2008). Based on the above, we propose the following:

H2a: Relational capital positively moderates the relationship between assessment practices and suppliers' social performance.

Initiating capability development and training programmes to address suppliers' social issues requires conducting joint activities with suppliers (Klassesn and Vereecke 2012). Trust between buyer and supplier contributes to the efficiency of joint operational activities and on-site supplier visits (Blonska et al. 2013; Liao et al. 2012). Mutual trust can help focal companies to improve collaboration with suppliers (Lawson et al. 2008) and facilitates collective actions (Coleman 1990). Furthermore, relational capital decreases heterogeneity between buyer and supplier and generates a mutual understanding of the value of capability development (Blonska et al. 2013). Collaboration practices also require the exchange of, and investment in, resources and technical skills (Klassesn and Vereecke 2012). Relational capital enhances the exchange of tangible and intangible resources among supply chain partners (Yim and Leem 2013) and can increase their motivation and commitment in the relationship (Kohtamäki et al. 2012). Moreover, relational capital reduces the risk associated with investments in supplier capability development (Blonska et al. 2013) and provides the confidence to make such investments (Chang and Gotcher 2007). Trust and close interaction with supply chain partners can lead to relationship learning (Chang and Gotcher 2007) and enables the institutionalisation of knowledge in relationship structures and working procedures (Huikkola et al. 2013). Trust also reduces governance costs by facilitating the necessary adaptations in supply chain relationships (Gulati and Nickerson 2008). In the context of SSCM, Gualandris and Kalchschmidt (2016) found strong evidence of the role of trust in governing relationships and enhancing supplier' sustainability performance. Therefore, we propose the following:

H2b: Relational capital positively moderates the relationship between collaboration practices and suppliers' social performance.

\subsubsection{The moderating role of cognitive capital}

The establishment of goal congruence between buyers and suppliers is an efficient mechanism to drive suppliers to comply with social sustainability standards (Pedersen and Andersen 2006). The process of supplier social monitoring and auditing entails setting objectives for suppliers to achieve and subsequently collecting and processing information from them (Huq et al. 2016; Klassesn and Vereecke 2012). Shared vision creates an understating between supply chain partners of how they should interact with one another (Inkpen and Tsang 2005). A common language facilitates 
communication and helps in setting explicit rules of coordination in supply chain relationships (Hughes and Perrons 2011; Johnson et al. 2013). A supplier's ability to receive and interpret the requirements from a focal company is one of the key aspects of successfully implementing social responsibility (Andersen and Skjoett-Larsen 2009). Shared goals and cognition provide a common understanding for supply chain members of what would represent improvements and how they can be achieved (Carey et al. 2011; Krause et al. 2007) as it enables partners to develop an understanding of each others' operations and processes (Lioliou and Zimmermann 2015). Shared values and common language also facilitate the process for buyers to assess a partner's activities (Wang et al. 2013) and monitor performance (Lioliou and Zimmermann 2015). According to Klassesn and Vereecke (2012), sharing a similar culture and understanding between buyer and supplier will lead to less monitoring and more precise reporting of the supplier's social performance. Likewise, a similar culture and shared norms can enhance procedural justice that in turn reduces the need for heavy monitoring and leads to better supplier compliance (Boyd et al. 2007). Therefore, we propose:

H3a: Cognitive capital positively moderates the relationship between assessment practices and suppliers' social performance.

The implementation of social responsibility best practices with suppliers entails organizations improving the depth of knowledge sharing and the embeddedness of jointly valuable practices (Gallear et al. 2012). A shared vision can help network members to integrate knowledge (Inkpen and Tsang 2005) and exchange resources (Pinheiro et al. 2016; Tsai and Ghoshal 1998). Moreover, shared vision increases the quality and accuracy of the shared information between buyer and supplier (Li et al. 2014). Cognitive capital through common goals and expectations was previously found to be positively related to the development of absorptive capabilities between exchange partners (Unal and Donthu 2014). A common understanding and approach to the achievement of relationship tasks enhances the collaboration capability of supply chain partners (Lioliou and Zimmermann, 2015). Initiating capability development and training programmes requires joint activities with suppliers (Klassesn and Vereecke 2012). Shared cognition can result in more efficient and effective processes (Bernardes 2010) and facilitates the collective actions of partners (Coleman 1990). Cognitive capital reflects a mutual commitment and agreed norms which can serve to support supply chain relationships and increase the willingness of partners to jointly improve performance (Son et al. 2016). Buyer-supplier collaboration on sustainability issues necessitates the exchange of, and investment in, resources and technical skills (Klassesn and Vereecke 2012). When a high level of shared values is present in the relationship a supplier will be unlikely to take advantage of a buyer (Lioliou and 
Zimmermann 2015; Wang et al. 2013). As a result, buyer and supplier will be willing to commit resources and investment to the relationship. Based on these arguments we propose:

H3b: Cognitive capital positively moderates the relationship between collaboration practices and suppliers' social performance.

\subsubsection{The moderating role of structural capital}

Through assessment practices, social standards are specified, performance is audited, feedback is provided, progress is monitored, and rewards (or punishments) are delivered to adjust suppliers' actions to meet pre-specified standards (Alghababsheh et al. 2018; Klassesn and Vereecke 2012; Sancha et al. 2015). This process therefore requires the gathering and processing of information from both buyers and suppliers (Grosvold et al. 2014). Information asymmetries between buyer and supplier can present a major obstacle to implementing socially responsible supply chains (Ciliberti et al. 2009). Social interactions offer a context for buyers and suppliers to share information and identify gaps that may exist in current work practices (Carey et al. 2011). Social interaction ties can increase the speed and content of information transfer (Johnson et al. 2013), thereby increasing the efficiency of gathering information (Nahapiet and Ghoshal 1998). Moreover, a supplier's ability to receive and interpret the requirements from a focal company is one of the key aspects of successfully implementing social responsibility (Andersen and Skjoett-Larsen 2009). Social interaction reduces uncertainty in the relationship by increasing the buyer's opportunities to evaluate the partner (Lee and Ha 2018; Wang et al. 2013). Moreover, establishing open communication with suppliers encourages compliance with social codes of conduct (Jiang 2009). Structural capital is argued to improve communication between supply chain partners and fosters a better understanding of each other's key processes and operations (Son et al. 2016). Maintaining high levels of structural capital enables supply chain partners to clarify the objectives of their arrangements, and explain the expectations and obligations of each partner (Lioliou and Zimmermann 2015). Based on the above we propose:

H4a: Structural capital positively moderates the relationship between assessment practices and suppliers' social performance.

Collaboration practices specifically require the exchange of resources and investments between buyer and supplier (Klassesn and Vereecke 2012; Sancha et al. 2015). Intensive social interactions reduce the risk associated with investments in buyer-supplier relationships by deterring opportunism and increasing willingness to allocate resources (Wang et al. 2013). Collaboration practices also require buyers and suppliers to exchange knowledge on new product development, and process redesign 
helps to guarantee health and safety for employees (Marshall et al. 2017), both be achieved by absorptive and innovative capabilities. Moreover, engaging in supplier capability development programmes requires the exchange of tacit and complex knowledge between buyer and supplier (Blonska et al. 2013). Structural capital increases transformation and exploitation capabilities of the new external knowledge (Wang and Li 2017). Similarly, structural capital with a supply chain partner improves process design and the capability of developing new products (Kulangara et al. 2016), and can increase learning in the buyer-supplier relationship (Wang et al. 2017). Suppliers' capability development and training programmes are executed through joint meetings and activities with suppliers (Klassesn and Vereecke 2012). Structural capital strengthens the relationships between buyer and supplier by creating solidarity (Adler and Kwon 2002), which in turn facilitates a mutual approach to problem-solving and commitment to joint actions (Poppo and Zenger 2002). Conversely, a lack of social interaction ties would make the acquisition of essential information costly and in some cases impossible (Villena et al. 2011). Furthermore, social disconnections can reduce information diffusion, weaken norms of reciprocity and create a fertile context of competition rather than collaboration (Hughes and Perrons 2011). Therefore, we propose the following:

H4b: Structural capital positively moderates the relationship between collaboration practices and suppliers' social performance.

\section{Methodology}

\subsection{Sample and data collection}

This study sought the participation of large manufacturing companies based in the UK representing the buyers' side in the relationship. The unit of analysis is the inter-organizational relationship between the buyer and the supplier. The large UK manufacturing companies provided a suitable context for the current study for a number of important reasons. Firstly, the UK is currently the ninth largest manufacturing nation by output in the world (accounting for $£ 192$ billion of output) (Make UK 2019) with extensive reliance on imported components from all parts of the world of many manufactured goods (Rhodes, 2020). However, the UK manufacturing industry has recently witnessed a number of supply-side social performance problems and issues, not least the collapse of Rana Plaza building in Bangladesh (killed 1,132 people and injured more than 2,500) which housed ready-made garment factories manufacturing for UK major retailers (such as Primark and Benetton) (ILO 2018), highlighting its importance as a suitable context for studying the phenomenon of socially SSCM. Second, whilst a wide range of social issues can exist in many different industries, working conditions and human rights issues (e.g., child labour, freedom of association, unfair payment, unpaid overtime, forced labour, working hours, and health and safety) tend to be more common and concentrated in 
the manufacturing sector and this is likely to be due to the labour-intensive nature of much of the activity within manufacturing supply chains (Bai and Sarkis 2010; Forsman-Hugg et al. 2013; Zorizini et al. 2015). Thirdly, because large companies are more likely to have greater knowledge, wider capabilities, and more resources compared to small and medium-sized enterprises (SMEs), arguable putting them in a better position to be (and to have been) able to invest and implement SSCM practices (Porteous et al. 2015; Walker and Jones 2012).

Using the Financial Analysis Made Easy (FAME) database as a sampling frame, a stratified random sample of 1,250 manufacturing companies operating in a variety of industrial sectors were selected. Following Dillman's (2007) Total Design Method, a mail survey accompanied by a prepaid envelope and a cover letter explaining the aim and importance of the study was personally addressed and administrated to chief executive officers (CEOs), supply chain, procurement, operations, purchasing and logistics managers within the selected sample. Out of the 1,250 questionnaires administrated, 132 questionnaires were received of which 119 were complete and usable for analysis. Following the instruction in the cover letter to direct the survey to the most knowledgeable individual, only three of the responses were received from two sustainability directors and one head of environment and quality system, possibly indicating a rather modest effort by firms towards investment to address sustainability issues. The titles held by the majority of respondents were directly related to socially SSCM confirming their suitability. The firms involved in this study varied in size, age, industry, and supplier-relationship length (see Table 1).

Insert Table (1) here

Non-response bias may arise when the participating respondents are different from those who have received the questionnaire but declined to participate (Armstrong and Overton 1977). Non-response bias was examined using the successive waves method suggested by Armstrong and Overton (1977). This method is suitable when a wave of responses is generated by a stimulus. The assumption of this method is that participants who answered in later waves are presumed to have answered due to the increased stimulus and are expected to be similar to non-participants. Accordingly, since a follow-up email had been sent to the respondents, the answers of the late respondents were compared with those provided by early respondents and the results suggested that non-response bias was not a concern. Nevertheless, non-response bias was further examined by collecting demographic information from the FAME database on those respondents who had received the questionnaire but did not complete it. Specifically, firm size and firm turnover between the respondents and non-

\footnotetext{
a FAME is a database contains information on companies in the UK and Ireland including contact, activities, ownership and financial
} information. 
respondents were compared. The $t$-test results indicated no statistically significant differences between participant and non-participant in firm size $(p=0.55)$ or firm turnover $(p=0.39)$, providing further evidence that non-response bias was not a concern.

\subsection{Measurement items}

All of the measurement items used were established scales adopted/adapted from the existing literature (see Appendix 1). Socially SSCM practices (i.e., assessment and collaboration practices) are all first order reflective constructs. The respondents were asked to indicate the level of the implementation of socially SSCM practices with a key supplier ranging from "not implemented $=1$ " to "fully implemented $=5$ ". Assessment practices were measured using six items based on the work of Lu et al. (2012) and Marshall et al. (2015). The respondents were requested to indicate the extent to which their companies have developed a code of conduct, conduct audits of health and safety, use certification as an indication of the supplier's responsible behaviour, assess the supplier's performance through formal evaluation, and provide feedback to the supplier. Collaboration practices were measured using four items adopted from Jiang (2009), Lu et al. (2012), and Marshall et al. (2015). The participants were asked to indicate the extent to which their companies offer the supplier financial incentives for compliance, visit the supplier's facilities, provide training and development for the supplier and develop a new product that reduced health and safety hazards for employees.

Social capital dimensions (i.e., relational, cognitive, and structural) are all first order reflective constructs and were measured on a 7-point Likert scale ranging from "strongly disagree $=1$ " to "strongly agree $=7$ ". Relational capital was captured using five items from Carey et al. (2011). The participants were asked to state if their relationships with suppliers are characterized by a close interaction, mutual trust, mutual respect, mutual friendship, and mutual reciprocity at multiple levels. Cognitive capital was measured using four items adopted from Villena et al. (2011) to indicate the degree of similarity between buyer and supplier in terms of organisational culture, philosophies, goals, and vision. Finally, structural capital was measured based on the work of Carey et al. (2011), Li et al. (2014), and Villena et al. (2011). The participants were asked to report if they communicate frequently, maintain personal interaction and close social relationships, and engage in social events with their supplier.

Supplier's social performance is a first order reflective construct (see Jarvis et al. 2003; Peng and Lai 2012) and was measured on a 7-point Likert scale ranging from "strongly disagree $=1$ " to "strongly agree $=7$ " using three items adopted from Sancha et al. (2015). Respondents were asked to indicate the extent to which they have improved safety and labour conditions, compliance with human rights and child labour employment in the supplier's facilities. 
It was essential to include control variables in the present research owing to their possible associations with the dependent variable. We controlled for two sources of heterogeneity: supplier dependency and relationship length. Supplier dependency is a reflective first order construct and was measured on a 7-point Likert scale ranging from "strongly disagree $=1$ " to "strongly agree $=7$ " using four items adopted from Jap and Ganesan (2000). The participants were asked to indicate to what extent the supplier is dependent on them. Relationship length was measured by the numbers of years the company has been doing business with the supplier.

\subsection{Common method bias}

Common method bias can potentially emerge from employing a self-administrated questionnaire to obtain data on the predictors and criterion variables from a single respondent at one point in time (Podsakoff et al. 2003), which it was case in this study. To avoid and attenuate potential common method bias, different procedures were followed at the research design stage (Guide and Ketokivi 2015; Podsakoff and Organ 1986; Rindfleisch et al. 2008). Firstly, different endpoints for the independent and outcomes measures were used as homogeneity in scale endpoints can give rise to methods biases (Crampton and Wagner 1994; Podsakoff et al. 2003; Rindfleisch et al. 2008). This measurement separation increases the respondent's cognitive processing, which encourages careful answering based on the item content (Rindfleisch et al. 2008). To recap, a 5 point Likert scale was utilised for socially SSCM practices with endpoints from "not implemented = 1" to "fully implemented $=5$ ", whereas a 7 point Likert scale with "strongly disagree $=1$ " to "strongly agree $=7$ " was used for social capital dimensions and supplier's social performance. Secondly, respondent's anonymity was ensured by sending a cover letter that explained the purpose of the study and that answers provided would be analysed at an aggregate level and no company level results would be revealed through any means (Podsakoff et al. 2003). Finally, potentially ambiguous or unfamiliar terms such as social capital were defined and explained in the survey (Podsakoff et al. 2003; Tourangeau et al. 2000).

Despite all the procedures that were followed at the research design stage, common method bias can still potentially occur. To examine for potential common method bias, Harman's (1976) single-factor test was used. In this test, all 30 items were loaded into factor analysis and the unrotated factor solution was examined to determine whether the majority of variance was caused by one factor (Podsakoff et al. 2003). The analysis indicated that the majority of variance explained in the model by a single factor $(25.15 \%)$ was less than the threshold value of $50 \%$, indicating that common method bias was not a critical issue. 


\section{Analysis and results}

We used partial least square structural equation modelling (PLS-SEM) for data analysis. SmartPLS 3.0 was employed to assess our measurement model and to estimate our structural model. Although its counterpart, covariance-based structural equation modelling (CB-SEM), is perceived as a robust multivariate approach to data analysis, PLS-SEM provides a superior data analysis approach in certain conditions, several of which were relevant in this study. Firstly, PLS-SEM produces more accurate estimates of interaction effects than other SEM techniques (Chin et al. 2003; Qureshi and Compeau 2009) and overcomes the problem of model identification and convergence problems when testing complex models using CB-SEM (Peng and Lai 2012). Testing a moderation effect under SEM is usually completed through a new construct that uses measures computed by cross-multiplying the standardized items of each construct in the moderating effect (Chin et al. 2003). Consequently, this cross-multiplying can potentially produce a large number of measures, thereby increasing the model complexity (Peng and Lai 2012). Secondly, PLS-SEM is useful when a research model is posited in a domain where theory is less developed and/or data are weak (Hair et al. 2014). Given that the social dimension of SSCM is lacking a well-developed theory (Beske-Janssen et al. 2015; Yawar and Seuring 2018; Zorzini et al. 2015) as evident by the few empirical studies that have examined the relationship between socially SSCM and suppliers' social performance (e.g., Sancha et al. 2016; Sancha et al. 2015) and the inconsistent results regarding the assessment practices-performance link, the focus of this study is on theory development. The study also aims to develop a theory of the moderating effect of social capital dimensions on the relationship between socially SSCM and suppliers' social performance, which has not been discussed before. Finally, PLS-SEM has the ability to estimate models with relatively smaller sample sizes (Hair et al. 2014; Reinartz et al. 2009) such as the 119 sample size of this study.

\subsection{Measurement model}

The quality of the measurement model was assessed in terms of reliability and validity. The reliability of the multi-item constructs was evaluated by obtaining the composite reliability coefficient (Werts et al. 1974). Since composite reliability prioritises items according to their weights (rather than assuming equivalency among the items) it is less sensitive to the number of items compared to Cronbach's alpha (Hair et al. 2014; Bacon et al. 1995). The constructs' composite reliability coefficients ranged from 0.81 to 0.93 and hence were all above the 0.7 threshold (Hair et al. 2014; Nunnally 1978), suggesting a satisfactory level of internal consistency (see Appendix 1 ).

The validity of the measurement model was examined at item (convergent validity) and construct (discriminant validity) level. To examine the convergent validity, standardised factor loadings of the 
items and the average variance extracted (AVE) of the construct were examined (Hair et al. 2014). The standardised factor loadings of the items on their associated constructs were higher than 0.5 and significant, which indicates that the items share something in common which is captured by the construct (Hair et al. 2014). All of the constructs' AVE values were greater than 0.5 suggesting that the variances explained in the items by their associated constructs are greater than their measurement error variances (Fornell and Larker 1981). Thus, all the constructs exhibited convergent validity.

To assess the discriminant validity of the constructs the heterotrait-monotrait (HTMT) ratio method (Henseler et al. 2015) was used. In their critical evaluation of the effectiveness of the most commonly used methods for assessing discriminant validity (i.e., Fornell and Larcker's criterion, constrained phi method, and overlapping confidence intervals), Voorhees et al. (2016) found that HTMT is the most efficient technique. The HTMT method was primarily developed to assess the discriminant validity in studies that employ a variance-based SEM. As a variance-based technique, PLS-SEM has a tendency to overestimate factor loadings that lead to an increase in AVE values, which can affect the ability of Fornell and Larcker's criterion (the-most commonly used method) to identify discriminant validity violations (Voorhees et al. 2016). Based on HTMT method, a construct can establish discriminant validity if the relationships of the items within the same construct are stronger than those of the items across constructs (Henseler et al. 2015). Table 2 shows that the HTMT ratios of the constructs were all below the threshold value of 0.85 , demonstrating discriminant validity (Henseler et al. 2015).

Insert Table (2) here

\subsection{Structural model}

The significance of path coefficients in PLS-SEM is obtained through a bootstrapping technique in which a larger number of samples are randomly drawn from the original data with replacement (Chin 1998). The larger the number of samples used during the bootstrapping process, the more robust the results will be (Hair et al. 2014). Accordingly, following Hair et al.'s (2014) suggestions, 5000 bootstrap samples were used. The structural model was tested in three hierarchal stages. In the first stage (model 1), the baseline model, all the control variables were introduced into the regression equation to control their possible effects on suppliers' social performance. In the second stage (model 2), all the independent and moderating variables were introduced to test their direct effects on suppliers' social performance. Model 1 and model 2 together are labelled as direct effects models. In the third stage (model 3), the full model, all interactions terms were introduced to test their potential effect on suppliers' social performance. 


\subsubsection{Direct effects models}

In model 1, introducing the control variables (relationship length and supplier dependency) explained .019 of suppliers' social performance (see Table 3). In model 2, compared with the baseline model, the addition of all the exogenous variables (assessment practices, collaboration practices, relational capital, cognitive capital, and structural capital) increased $R^{2}$ for suppliers' social performance significantly from to $0.34\left(\Delta R^{2}=0.32\right)$. The results also indicate that the relationships between assessment practices and suppliers' social performance is insignificant $(\beta=.11, p>0.05)$, whilst the relationship between collaboration practices and suppliers' social performance is positive and significant $(\beta=.21, p<0.01)$. These results therefore provide no support to $\mathrm{H} 1 \mathrm{a}$, but do provide support for $\mathrm{H} 1 \mathrm{~b}$.

Insert Table (3) here

\subsubsection{Interaction effect model}

As building the interaction term from the indicators of both the independent and moderating variables can lead to multicollinearity issues (Aiken and West 1991; Dawson 2014), we standardised its indicators (i.e., deducting the mean from the score of the indicator then dividing it by the standard deviation so it has a mean of zero and standard deviation of 1). In the interaction effect model (model 3) all the interaction terms were added into the main direct models (model 1 and 2). The addition of these interaction terms increased $R^{2}$ for suppliers' social performance significantly from 0.34 to 0.46 $\left(\Delta R^{2}=0.12\right)$. The effect size $f^{2}$ of the interaction effect was 0.22 , suggesting a moderate effect size (Cohen 1992).

The results indicate that the moderating effect of relational capital on the relationship between assessment practices and suppliers' social performance $(\beta=0.28, p<0.01)$ and on the relationship between collaboration practices and suppliers' social performance $(\beta=0.35, p<0.01)$ is significant, providing support for $\mathrm{H} 3 \mathrm{a}$ and $\mathrm{H} 3 \mathrm{~b}$. The results also demonstrate that the moderating effect of cognitive capital on the relationship between assessment practices and suppliers' social performance is insignificant $(\beta=0.12, p<0.05)$, while its effect on the relationship between collaboration practices and suppliers' social performance is significant $(\beta=0.23, p<0.01)$. Thus, these results provide support to $\mathrm{H} 4 \mathrm{~b}$, but not to $\mathrm{H} 4 \mathrm{a}$. The results also reveal that the moderating effect of structural capital on the relationship between assessment practices and suppliers' social performance is significant ( $\beta=0.27$, $p<0.01$ ), whilst its effect on the relationship between collaboration practices and supplier's social performance is insignificant $(\beta=0.18, p<0.05)$. Thus, these results provide support for $\mathrm{H} 5 \mathrm{a}$ but not to $\mathrm{H} 5 \mathrm{~b}$. 


\section{Discussion}

\subsection{Socially SSCM practices and suppliers' social performance}

The study found no support for the relationship between assessment practices and suppliers' social performance. Thus, introducing a code of conduct and certification system and performing auditing and monitoring by buyers to improve suppliers' social performance was found to be ineffective. This is in line with the results reported by Sancha et al. (2016) who found, using data from Spanish manufacturing companies, that monitoring and auditing suppliers had no impact on supplier's social performance. Likewise, Jiang (2009) demonstrated that setting up standards and coercing noncompliant suppliers to increase commitment to the code of conduct would not help in reducing social failures in suppliers' factories. Similarly, Yu (2008) revealed that the implementation of a code of conduct was not only ineffective in curbing low-wage payment and promoting worker's right to freedom of association and collective bargaining but increased the scale of these unethical actions by suppliers. The lack of association between assessment practices and suppliers' social performance could be explained by the fact that assessment practices are mainly used by buyers to obtain detailed information regarding current social issues without also precipitating effective actions such as training or financial support to understand and resolve them. Another explanation might be that the use of assessment-based governance to establish SSCM creates a perception of inequity by suppliers (given that suppliers usually bear the majority of the costs of these practices), which in turn leads to noncompliance (Normann et al. 2017) or just symbolic compliance (Huq et al. 2014).

The study found evidence to support the positive relationship between collaboration practices and suppliers' social performance. That is to say, that close work with suppliers on social issues through supplier training, allocating necessary resources, and joint activities are effective vehicles to enhance suppliers' social performance. This result is consistent with the findings reported by Sancha et al. (2015) and Sancha et al. (2016) who found that collaboration and supplier development practices should be put in place if buyers are to increase suppliers' compliance with human rights, reduce child labour employment, and improve safety and labour conditions at their facilities. The study findings also corroborate previous findings of Huq et al. (2016) who found that buyers establish the ground for improved supplier internal and external social conditions by building social management capabilities in the form of collaborating with suppliers and other stakeholders (e.g., NGOs). In contrast to assessment practices, it is reasonable to argue that the positive impact of collaboration practices on suppliers' social performance is a result of the interaction routines established between buyer and supplier that foster mutual learning, resources sharing and knowledge exchange, enabling suppliers to build specific capabilities to improve their social performance (Gualandris and Kalchschmidt 2016). 
It could also be argued that suppliers improved capabilities resulting from social development programmes has improved their financial position, which in turn enables them to make more investment in work infrastructures and to provide better labour rights (Yawar and Seuring 2018).

\subsection{The moderating effect of social capital}

\subsubsection{The moderating role of relational capital}

The study found that relational capital positively moderates the relationship between assessment practices and suppliers' social performance. Thus, the use of assessment practices can achieve the intended aim of improving suppliers' social performance when mutual trust, friendship, and respect and high level of reciprocity are established between buyer and supplier. A similar result was reported by Blonska et al. (2013) who found that normally indirect supplier development practices (e.g., monitoring and assessment) were often detrimental to suppliers' benefit in the relationship, however under a high level of relational capital indirect supplier development was positively related to suppliers' benefit because relational capital guaranteed the achievement of supplier development objectives as planned. Our result is also consistent with the complementary view of formal and relational governance (trust) in governing inter-organisational buyer-supplier relationships (e.g., Poppo and Zenger 2002; Gulati and Nickerson 2008). The view contends that the best performance outcome of any exchange relationship can be achieved by simultaneously using formal and relational governance (Gulati and Nickerson 2008; Liu et al. 2009; Poppo and Zenger 2002). This is because trust (relational capital) reduces transactional costs and opportunism and facilitates coordination (Nahapiet and Ghoshal 1998; Wang et al. 2013). In turn, formal governance (e.g., code of conduct and certification) provides a formal specification of duties and responsibilities and a frame of reference for dispute resolution in the relationship (Poppo and Zenger 2002; Liu et al. 2009). Thus, relational governance overcomes the deficiency of transactional contracts, and vice versa (Liu et al. 2009).

The analysis also found that relational capital positively moderates the relationship between collaboration practices and suppliers' social performance. This means that the positive impact of collaboration practices on suppliers' social performance is stronger when trust and respect are embedded in the buyer-supplier relationship. Thus, relational capital indirectly improves suppliers' social performance by facilitating different aspects of collaboration practices including joint activities, knowledge and resources sharing, mutual communication, commitment, and participation. This result is compatible with the growing number of studies highlighting the critical role of relational capital in facilitating the collaboration between buyer and supplier on different aspects/activities in the relationship. For example, Huikkola et al. (2013) indicated that relational capital in the form of trust and friendship enables joint learning in R\&D collaboration by facilitating knowledge sharing and 
effective collaboration, opening dialogue and providing agreement between partners. Similarly, trust between buyer and supplier contributes to the efficiency of joint operational activities and on-site supplier visits aimed to improve suppliers' capabilities and overall performance (Blonska et al. 2013; Liao et al. 2012). Likewise, Kohtamäki et al. (2012) pointed out that relational capital facilitates further the positive effects of enabling structures (i.e., steering groups, joint development groups, integrated IT system, and process description) on relationship performance in subcontractor and customer relationships.

\subsubsection{The moderating role of cognitive capital}

Our data provided no support for the prediction that cognitive capital in the buyer-supplier relationship strengthens the relationship between assessment practices and suppliers' social performance. Thus, sharing similar organisational culture and vision and having compatible goals and objectives with suppliers appears to not support the implementation of assessment practices (i.e., auditing, monitoring and certification). The reason for this result is not entirely clear, but it may be that cognitive capital between buyer and supplier in the study sample has yet to be well developed. Assessment practices are usually used and implemented by buying firms to tackle suppliers' social issues with whom they have transactional relationships. Transactional relationships (arm's-length) are short-term and do not provide enough opportunities for sustained interaction and conversations which is a precondition for the development and maintenance of dense social capital (Nahapiet and Ghoshal 1998). Moreover, the short-term and unstable nature of many transactional relationships can hinder the development of clear mutual understandings between buyer and supplier (Misztal 1996). Furthermore, buying firms often establish monitoring or auditing systems to help mitigate shortcomings derived from limited access to information and uncertain commitment as geographic distance between them and suppliers increases (Koplin et al. 2007). As the distance between relationship partners increases, developing a high level of cognitive capital will be less likely (Nahapiet and Ghoshal 1998).

In contrast to assessment practices, our analysis confirmed that cognitive capital in the buyer-supplier relationship positively moderates the relationship between collaboration practices and suppliers' social performance. It indicates that the positive impact of collaboration practices on suppliers' social performance is amplified under a higher level of cognitive capital. It seems that the alignment between buyer and supplier goals and shared vision improves the implementation of collaboration practices by increasing the communication level and information sharing, which subsequently improves suppliers' social performance. This is broadly consistent with the emerging literature explicating the derived value from social capital embedded in buyer-supplier relationships. For example, Hung et al. (2014) 
suggested that cognitive capital facilities both knowledge inflow and outflow in the green supply chain, which in turn leads to improved green supply chain performance. Similarly, Johnson et al. (2013) found that common language and codes reduce the costs of communication and help in setting explicit rules of coordination which facilities the development of four formative capabilities (i.e., flexibility, velocity, visibility, and collaboration) for supply chain resilience. Likewise, Lioliou and Zimmermann (2015) and Wang et al. (2013) emphasised that when a high level of shared values is manifested in the buyersupplier relationship, opportunism will be unlikely to occur due to reduced uncertainty. As a result, both parties will be more willing to commit resources and investment during the implementation of collaboration practices, which arguably further increases their positive impact on suppliers' social performance.

\subsubsection{The moderating role of structural capital}

The findings revealed that structural capital positively moderates the relationship between assessment practices and suppliers' social performance. This implies that as buyers and suppliers establish frequent and strong social interactions, the use of assessment practices (i.e., auditing, monitoring and certification) becomes effective in enhancing the social conditions at suppliers' workplaces. The assessment approach is widely implemented by buyers to capture and understand suppliers' current internal social conditions with less follow up and continuous direct involvement from buyers (Sancha et al. 2016). With such an approach, buyers also often audit and leave a supplier with an unrealistic set of targets to meet with no support and assistance (Huq et al. 2014; Jiang 2009). Buyer and supplier need to coordinate, exchange and process information from both sides in order to achieve the goals of assessment practices (Grosvold et al. 2014). In this sense, our research supports the view that social interactions offer a context for buyers and suppliers to share information and identify gaps that may exist in current work practices (Carey, Lawson, and Krause 2011). Structural capital improves communication between supply chain partners and fosters a better understanding of each other's key processes and operations (Son et al. 2016). It also enables supply chain partners to clarify the objectives of their arrangements, and explain the expectations and obligations of each partner (Lioliou and Zimmermann 2015). Thus, structural capital facilitates the core aspects of assessment practices which involve setting objectives, monitoring progress, auditing, and providing feedback to align suppliers' behaviour with buyers' criteria (Klassesn and Vereecke 2012).

Unexpectedly, the analysis indicated that structural capital does not moderate the relationship between collaboration practices and suppliers' social performance. Thus, the positive impact of collaboration practices (i.e., training, development, and joint activities) on suppliers' social performance is constant regardless of the presence, level, and strength of social interactions between 
buyers and suppliers. Our finding runs counter to similar prior studies that examined the role of structural capital on aspects of collaboration in the buyer-supplier relationship. For instance, Yim and Leem (2013) reported that structural capital facilitates supply chain integration in the form of information sharing, collaboration, and resource exchange. Similarly, Johnson et al. (2013) revealed that all social capital dimensions facilitate and enable collaboration as one of firm's supply chain resilience capabilities. Nevertheless, our counterintuitive result may be explained by the fact that it is very likely that structural capital facilitates the implementation of assessment practices, but has no role in the case of collaboration practices since collaboration practices represent forms of strong interactions and ties between buyer and supplier (Krause et al. 2007). More specifically, structural capital (i.e., establishing frequent communication, intensive interaction, and close social relationships) may not add value and further magnify the positive impact of collaboration practices on suppliers' social performance since they share similar aspects. Another possible explanation is that although moderate levels of frequent and close interaction in the relationship can enable information and resource exchange, higher levels may in fact hinder such exchange, undermining the effectiveness of collaboration. This is consistent with the 'dark side' of social capital, which suggests that when buyer and supplier interact more (too) frequently and closely, the likelihood of opportunism (Villena et al. 2011) and ineffective decision making (Chou et al. 2006) increases, while information flow and new innovative ideas decrease (Cho et al. 2017).

\section{Conclusions and implications}

The study set out to examine buyers' perceptions of the effects of assessment and collaboration practices on suppliers' social performance and whether these effects are moderated (strengthened) by the level of social capital (i.e., relational, cognitive, and structural) embedded in the buyer-supplier relationship. Our analysis based on 119 manufacturing companies in the UK suggested mixed results for the hypothesised relationships. The results revealed that assessment practices are not as effective to drive suppliers' social performance (i.e., to reduce unethical practices, notably poor labour and safety conditions, non-compliance with human rights, and child labour employment) compared to collaboration practices. However, when relational and structural capital are manifested in the relationship, assessment practices become significant in driving suppliers' social performance. The results also uncovered that the positive impact of collaboration practices is more pronounced when relational and cognitive capital are established in the relationship. These results have implications for theory and practice. 


\subsection{Theoretical implications}

This study contributes to SSCM literature and to the broader literature on inter-organizational social capital in the buyers-supplier relationship in three important ways. First, our study exclusively examines the social dimension of SSCM (i.e., assessment and collaboration) and its effect on suppliers' social performance. This adds necessary balance to the literature which has predominantly focused on the environmental side of sustainability. Although SSCM has received considerable research attention over the last few years (Carter and Washispack, 2018), it is clearly evident that the social dimension has received much more limited attention (Zorzini et al. 2015). Our exclusive focus on the social dimension also advances the current literature by providing a clearer and deeper understanding of the impact of pursuing social initiatives in the supply chain on performance. Although a large number of studies have examined the link between the green (environmental) supply chain practices and performance, the relationship between socially SSCM practices and suppliers' social performance has received scant attention (Ahi and Searcy 2015). However, the majority of prior research that has exmained the social perofrmance of SSCM has combined environmental and social dimensions into a single concept, thus assuming that the findings on the environmental dimension are also applicable to the social dimension, which creates theoretical ambiguity as to whether pursuing social programmes in the supply chain (vs environmental programmes) can drive performance (Huq and Stevenson 2018; Klassen and Vereecke 2012; Porteous et al. 2015). We empirically revealed that imposing codes of conduct, performing audits of health and safety conditions, using certification system, and evaluating suppliers' operations according to established guidelines and procedures do not translate directly into improved working conditions of, and reduced unethical employment practices within, suppliers' workplace environment. Our analysis instead highlights that visiting suppliers to help improve their performance, establishing dedicated supplier social development programmes, and developing new product/processes with suppliers can lead to significant improvement.

Second, this study theorized and empirically examined the moderating role of social capital dimensions (i.e., relational, cognitive, and structural) on the relationship between socially SSCM practices (i.e., assessment and collaboration) and suppliers' social performance, which has not been discussed before. This advances the current knowledge on SSCM by articulating how relational, cognitive, and structural capital can underpin and enable an effective and successful implementation of socially SSCM practices (assessment and collaboration) to sustain suppliers' social performance. We highlighted that establishing trust, mutual respect, and friendship with suppliers (relational capital) can motivate both partners to cooperate and commit to the implementation of both assessment and collaboration practices by improving the exchange and transfer of information and knowledge, the 
allocation of the needed resources, and the efficiency of joint activities such as development programmes. We also demonstrated that the development of shared understandings and system of meanings in the relationship enhances the impact of collaboration practices on suppliers' social performance by facilitating information sharing and collective actions. We also highlighted that the existence of frequent social interactions in the relationship provides a conduit for buyers and suppliers to share information, to explain their expectations and obligations, and to reduce uncertainty in the relationship during the implementation of the assessment practices, which in turn become a significant driver of suppliers' social performance.

Third, the study also contributes to the literature on inter-organizational social capital in the buyersupplier relationship by exploring the role of all social capital dimensions simultaneously on the implementation of different socially SSCM practices. This has extended prior research which has predominately tended to focus on examining the impact of social capital dimensions on traditional relationship outcomes, including strategic performance (e.g., Villena et al. 2011; Son et al. 2016), operational performance (e.g., Lawson et al. 2008; Zhang et al. 2017), relationship learning (e.g., Li 2010; Kohtamäki et al. 2013), opportunism (Wang et al. 2013; Lioliou and Zimmermann 2015), knowledge sharing (Li et al. 2014), and integration (Yim and Leem 2013), by providing more in-depth explanation about how social capital contributes to non-traditional cooperation in the relationship, namely the implementation of socially SSCM practices. Additionally, our nuanced model of all three prevalent social capital dimensions extends the extant research which has mainly concentrated on examining only specific social capital dimension(s). Our study has thus disentangled the unique role and distinct importance of each dimension on the implementation of assessment and collaboration practices. Our findings suggested that overall, relational capital has the strongest effect on the implementation of socially SSCM practices relative to cognitive and structural capital, by facilitating the implementation of both assessment and collaboration practices. Cognitive capital enhanced the implementation of only collaboration practices, while structural capital improved the implementation of only assessment practices.

\subsection{Managerial implications}

This study provides practical implications on how to successfully implement socially SSCM practices to tackle social issues at suppliers' workplaces. Firstly, by adopting assessment practices - such as heavy auditing of suppliers' operations, requesting suppliers to obtain third-party certification and/or providing self-assessment reports - to tackle suppliers' social deficiencies appears to be ineffective. In contrast, engaging in collaborative practices - by starting supplier development and training programmes, and through joint-efforts, knowledge exchange and committing to relationship-specific 
resources - has the potential to enhance the social conditions within suppliers' internal environment. Thus, supply chain managers who are currently implementing socially SSCM practices should place more emphasis on the collaborative practices. Nevertheless, it should be borne in mind that the collaboration approach might only be feasible with a limited number of suppliers given its need for intensive resources and longer time to establish, implement, and achieve the expected outcomes. Secondly, supply chain managers can increase the potential of the assessment practices, and hence are able to make observable enhancements in the social conditions at suppliers' workplace, when mutual trust and frequent social interactions are established with suppliers, and can increase the effectiveness of the collaboration practices when trust and shared understanding are prevalent with suppliers. Therefore, to ensure a smooth and effective implementation of socially SSCM practices, supply chain managers should actively promote the development of all social capital dimensions (relational, cognitive, and structural capital) with suppliers rather than being selective. Supply chain managers should work towards establishing trust, respect and friendship with suppliers and to work regularly towards aligning their values and goals and developing mutual understanding of their business environments, operations, and processes. They should also try to improve social interactions with suppliers in terms of frequency and strength. All of this can be achieved by engaging and investing in activities and channels that serve as a platform to foster intense and ongoing interactions with suppliers and creating the conditions that promote such interactions. For example, holding regular relationship meetings and social events, establishing integrated information and communication systems, and organising mutual factory visits in a context of transparency and fair relationship would be rich mechanisms to develop trust, shared purpose and interactions routines in the relationship.

\section{Limitations and future research}

Despite the contribution of this study, the study is not without limitations, several of which can be addressed through or serve as fertile grounds for future research on socially SSCM. Firstly, our conceptual model was tested using a sample from large manufacturing companies operating in the UK. Although this setting and design help to control for industry (manufacturing vs service) and country-level variations as potential noise in testing the model, it may limit the generalizability of the results due to industry and culture-specific characteristics. Future research could replicate the study in different settings including other countries and in the service industry. Moreover, this study examined the buyers' perception of the effects of socially SSCM practices on suppliers' social performance, which may not fully reveal their true impacts on suppliers' social performance. Future research should also seek the perspective of suppliers, especially those located in developing countries. In doing so however, while the suppliers' perspective per se would contribute an 
understanding of how suppliers perceive the implementation of socially SSCM with buyers, canvassing the views of the suppliers' top managers may potentially introduce a degree of bias due to the natural inclination not to want reveal social performance deficiencies. Thus, it would more appropriate and reliable to capture suppliers' social performance from the operational employees' perspective which is more likely to reflect the true working conditions and health and safety levels. Furthermore, future scholarship could extend our study by exploring whether the impact of socially SSCM practices on social performance varies depending on suppliers' location (i.e., local vs global).

Secondly, our study found that assessment practices do not directly improve suppliers' social performance. The implementation of this specific type of socially SSCM practice may create tensions in the buyer-supplier relationship through buyers requiring suppliers to invest and expend costs on certification, auditing, and improving health and safety in the workplace, whilst simultaneously demanding price reductions, shorter lead times, and higher quality component parts. This in turn may lead to suppliers' perception of exploitation and unfairness. Therefore, there is an urgent need for indepth exploratory work to look deeply into whether specific approaches to tackling the social issues of suppliers (e.g., assessment and monitoring) can lead to unexpected or even detrimental consequences in the relationship such as conflict, relationship dissolution, and opportunistic behaviour. These possible negative outcomes could be explored as mediating variables to better explain and understand why the assessment practices do not always translate into positive social performance. Once the mechanism(s) explaining why assessment practices do not lead to social performance are better understood, understanding how assessment practices can lead to social performance can be comprehended though identifying moderating variables to counter, mitigate, or eliminate unintended consequences of assessment practices.

Thirdly, although our study has revealed that the collaboration practices are more effective for enhancing supply chain social sustainability compared to assessment practices, growing research has revealed that some of its characteristics have hindered its widespread implementation (e.g., LundThomas and Lindgreen 2014). The costly nature of the collaboration practices and the need for longer time to establish, implement, and achieve the expected outcomes (Grosvold et al. 2014; Klassen and Vereecke 2012) may raise buyers' fears of potential opportunistic behaviours by suppliers and thus lead to a higher level of implementation failure. Therefore, an important future research priority should be to identify and explore the conditions and circumstances under which the collaboration practices are most effectively and successfully implemented. For instance, it would be prudent to explore how the 'quality' of the suppliers' institutional environment (e.g., the level of corruption and adherence to legal parameters) of suppliers might moderate the relationship between the 
collaboration practices and suppliers' social performance. It might be expected that a 'low quality' of suppliers' institutional environment would undermine the effectiveness of collaboration practices to address suppliers' social deficiencies and vice versa.

Finally, to mitigate the risks to their reputation and image that can arise from suppliers' unethical actions international buyers increasingly demand suppliers to meet specific social performance standards (Ehrgott et al. 2011; Yadlapalli et al. 2018). This has led suppliers to implement different social sustainability practices to improve workplace conditions and to contribute to the community in which they operate (Huq et al. 2014) in order to be able to stay competitive when higher quality, lower prices, and shorter lead times are no longer a guarantee of securing orders from international buyers on their own (Alghababsheh et al. 2018). Although this suggests that the adoption of social sustainability practices by suppliers may enhance their competitive position, empirical evidence determining whether these practices would improve suppliers' sales and export performance is surprisingly lacking. An insightful avenue for future research would therefore be to empirically examine the impact of social sustainability practices on suppliers' export performance and consider potential mediating variables such as social performance and operational performance in this relationship. This would advance the current knowledge by exploring a new performance outcome that could be enhanced by implementing socially SSCM and by articulating the mechanisms through which social sustainability practices can potentially lead to improved export performance.

\section{Compliance with Ethical Standards}

Conflict of interest. No potential conflict of interest was reported by the authors.

\section{References}

Adler, P. S., \& Kwon, S. W. (2002). Social capital: Prospects for a new concept. Academy of Management Review, 27(1), 17-40.

Ahi, P., \& Searcy, C. (2015). Measuring social issues in sustainable supply chains. Measuring Business Excellence, 19(1), 33-45.

Aiken, L. S., \& West, S. G. (1991). Multiple regression: Testing and interpreting interactions. Newbury Park, CA: Sage.

Alghababsheh, M. (2018). The implementation of socially sustainable supply chain management in the UK manufacturing sector: A social capital perspective, Unpublished doctoral dissertation, Brunel University London, London, United Kingdom.

Alghababsheh, M., Gallear, D., \& Rahman, M. (2018). Balancing the Scales of Justice: Do Perceptions of Buyers' Justice Drive Suppliers' Social Performance?. Journal of Business Ethics, 1-26, https://doi.org/10.1007/s10551-018-3993-0 
Andersen, M., \& Skjoett-Larsen, T. (2009). Corporate social responsibility in global supply chains. Supply Chain Management: An International Journal, 14(2), 75-86.

Armstrong, S., \& Overton, T. (1977). Estimating Nonresponse Bias in Mail Surveys. Journal of Marketing Research, 14(3),396-402.

Awaysheh, A., \& Klassen, R. D. (2010). The impact of supply chain structure on the use of supplier socially responsible practices. International Journal of Operations \& Production Management, 30(12), 1246-1268.

Bacon, D. R., Sauer, P. L., \& Young, M. (1995). Composite reliability in structural equations modeling. Educational and Psychological Measurement, 55(3), 394-406.

Bai, C. and Sarkis, J. (2010). Integrating sustainability into supplier selection with grey system and rough set methodologies. International Journal of Production Economics, 124 (1), 252-264.

Baker, W. E. (1990). Market networks and corporate behavior. American Journal of Sociology, 96(3), 589-625.

Barney, J. (1991). Firm resources and sustained competitive advantage. Journal of Management, 17(1), 99-120.

Bernardes, E. S. (2010). The effect of supply management on aspects of social capital and the impact on performance: A social network perspective. Journal of Supply Chain Management, 46(1), 4555 .

Beske-Janssen, P., Johnson, M. P., \& Schaltegger, S. (2015). 20 years of performance measurement in sustainable supply chain management-what has been achieved?. Supply chain management: An international Journal, 20(6), 664-680.

Blonska, A., Storey, C., Rozemeijer, F., Wetzels, M., \& de Ruyter, K. (2013)., Decomposing the effect of supplier development on relationship benefits: The role of relational capital. Industrial Marketing Management, 42(8), 1295-1306.

Boyd, D. E., Spekman, R. E., Kamauff, J. W., \& Werhane, P. (2007). Corporate social responsibility in global supply chains: a procedural justice perspective. Long Range Planning, 40(3), 341-356.

Burt, R. S. (1997). The contingent value of social capital. Administrative Science Quarterly, 42(2), 339365.

Carey, S., Lawson, B., \& Krause, D. R. (2011). Social capital configuration, legal bonds and performance in buyer-supplier relationships. Journal of Operations Management,29(4),277-288.

Carter, C. R., \& Washispack, S. (2018). Mapping the Path Forward for Sustainable Supply Chain Management: A Review of Reviews. Journal of Business Logistics, 39(4), 242-247.

Chang, K. H., \& Gotcher, D. F. (2007). Safeguarding investments and creation of transaction value in asymmetric international subcontracting relationships: The role of relationship learning and relational capital." Journal of World Business,42(4),477-488.

Chin, W. W. (1998). The Partial Least Squares Approach to Structural Equation Modeling. In Modern Methods for Business Research, edited by G. A. Marcoulides, 295-336. Mahwah, NJ: Lawrence Brlbaum Associates. 
Chin, W. W., Marcolin, B. L., \& Newsted, P. R. (2003). A partial least squares latent variable modeling approach for measuring interaction effects: Results from a Monte Carlo simulation study and an electronic-mail emotion/adoption study. Information Systems Research,14(2), 189-217.

Cho, M., Bonn, M. A., Giunipero, L., \& Jaggi, J. S. (2017). Contingent effects of close relationships with suppliers upon independent restaurant product development: A social capital perspective. International Journal of Hospitality Management, 67, 154-162.

Chou, T. C., Chen, J. R., \& Pan, S. L. (2006). The impacts of social capital on information technology outsourcing decisions: A case study of a Taiwanese high-tech firm. International Journal of Information Management, 26(3), 249-256.

Ciliberti, F., de Groot, G., de Haan, J., \& Pontrandolfo, P. (2009). Codes to coordinate supply chains: SMEs' experiences with SA8000. Supply Chain Management: An International Journal, 14(2), 117-127.

Cohen, J. (1992). A power primer. Psychological Bulletin, 112(1), 155-159.

Coleman, J.S. (1990). Foundations of Social Theory. Cambridge: Belknap Press.

Crampton, S. M., \& Wagner III, J. A. (1994). Percept-percept inflation in microorganizational research: An investigation of prevalence and effect. Journal of Applied Psychology, 79(1), 67-76.

Dawson, J. F. (2014). Moderation in management research: What, why, when, and how. Journal of Business and Psychology, 29(1), 1-19.

Dillman, D. A. (2007). Mail and internet surveys - the tailored design method. (2nd edn). New York: Wiley.

Dubey, R., Gunasekaran, A., Childe, S. J., \& Papadopoulos, T. (2018). Skills needed in supply chainhuman agency and social capital analysis in third party logistics. Management Decision, 56(1), 143-159.

Dyer, J. H., \& Singh, H. (1998). The relational view: Cooperative strategy and sources of interorganizational competitive advantage. Academy of Management Review, 23(4), 660-679.

Ehrgott, M., Reimann, F., Kaufmann, L., \& Carter, C. R. (2011). Social sustainability in selecting emerging economy suppliers. Journal of Business Ethics, 98(1), 99-119.

Foerstl, K., Reuter, C., Hartmann, E., \& Blome, C. (2010). Managing supplier sustainability risks in a dynamically changing environment-Sustainable supplier management in the chemical industry. Journal of Purchasing and Supply Management, 16(2), 118-130.

Fornell, C., \& Larcker, D. F. (1981). Structural equation models with unobservable variables and measurement error: Algebra and statistics. Journal of Marketing Research, 18(3), 382-388.

Gallear, D., Ghobadian, A., \& Chen, W. (2012). Corporate responsibility, supply chain partnership and performance: An empirical examination. International Journal of Production Economics, 140(1), 83-91.

Grosvold, J., U. Hoejmose, S., \& K. Roehrich, J. (2014). Squaring the circle: Management, measurement and performance of sustainability in supply chains. Supply Chain Management: An International Journal, 19(3), 292-305. 
Grover, V., \& Malhotra, M. K. (2003). Transaction cost framework in operations and supply chain management research: theory and measurement. Journal of Operations Management, 21(4), 457-473.

Gualandris, J., \& Kalchschmidt, M. (2016). Developing environmental and social performance: the role of suppliers' sustainability and buyer-supplier trust. International Journal of Production Research, 54(8), 2470-2486.

Guide, V. D. R., \& Ketokivi, M. (2015). Notes from the Editors: Redefining some methodological criteria for the journal. Journal of Operations Management, 37: v-viii.

Gulati, R., \& Nickerson, J. A. (2008). Interorganizational trust, governance choice, and exchange performance. Organization Science, 19(5), 688-708.

Hair, J. F., Hult, G. T. M., Ringle, C. M., \& Sarstedt, M. (2014). A primer on partial least squares structural equation modeling (PLS-SEM). Thousand Oaks: Sage.

Harman, H.H. (1967). Modern Factor Analysis. (2nd edn). Chicago: University of Chicago Press.

Henseler, J., Ringle, C. M., \& Sarstedt, M. (2015). A new criterion for assessing discriminant validity in variance-based structural equation modeling. Journal of the Academy of Marketing Science, 43(1), 115-135.

Hughes, M., \& Perrons, R. K. (2011). Shaping and re-shaping social capital in buyer-supplier relationships. Journal of Business Research, 64(2), 164-171.

Huikkola, T., Ylimäki, J., \& Kohtamäki, M. (2013). Joint learning in R\&D collaborations and the facilitating relational practices. Industrial Marketing Management, 42(7), 1167-1180.

Hung, S. W., Chen, P. C., \& Chung, C. F. (2014). Gaining or losing? The social capital perspective on supply chain members' knowledge sharing of green practices. Technology Analysis \& Strategic Management, 26(2), 189-206.

Huq, F. A., \& Stevenson, M. (2018). Implementing Socially Sustainable Practices in Challenging Institutional Contexts: Building Theory from Seven Developing Country Supplier Cases. Journal of Business Ethics, 1-28.

Huq, F. A., Chowdhury, I. N., \& Klassen, R. D. (2016). Social management capabilities of multinational buying firms and their emerging market suppliers: An exploratory study of the clothing industry. Journal of Operations Management, 46, 19-37.

Huq, F. A., Stevenson, M., \& Zorzini, M. (2014). Social sustainability in developing country suppliers: An exploratory study in the ready made garments industry of Bangladesh. International Journal of Operations \& Production Management, 34(5), 610-638.

Inkpen, A. C., \& Tsang, E. W. (2005). Social capital, networks, and knowledge transfer. Academy of Management Review, 30(1), 146-165.

International Labour Organization (2017). Global Estimates of Modern Slavery: Forced Labour and Forced Marriage. Geneva, Switzerland: Author. Retrived November 14, 2018 from https://www.ilo.org/global/publications/books/WCMS 575479/lang--en/index.htm.

International Labour Organization (2018). Bangladesh Move towards Employment injury Insurance: The Legacy of Rana Plaza. Geneva, Switzerland: Author. Retrived February 13, 2020 from https://www.ilo.org/global/topics/geip/publications/WCMS 632364/lang--en/index.htm. 
Jap, S. D., \& Ganesan, S. (2000). Control mechanisms and the relationship life cycle: Implications for safeguarding specific investments and developing commitment. Journal of Marketing Research, $37(2), 227-245$.

Jarvis, C. B., Mackenzie, S. B., and Podsakoff, P. M. (2003). A critical review of construct indicators and measurement model misspecification in marketing and consumer research. Journal of Consumer Research, (30)2, 199-218.

Jiang, B. (2009). The Effects of Interorganizational Governance on Supplier's Compliance with Scc: An Empirical Examination of Compliant and Non-Compliant Suppliers. Journal of Operations Management, 27(4), 267-280.

Johnson, N., Elliott, D., \& Drake, P. (2013). Exploring the role of social capital in facilitating supply chain resilience. Supply Chain Management: An International Journal, 18(3), 324-336.

Kale, P., Singh, H., \& Perlmutter, H. (2000). Learning and protection of proprietary assets in strategic alliances: Building relational capital. Strategic Management Journal, 21(3), 217-237.

Klassen, R. D. \& Vereecke, A. (2012). Social Issues in Supply Chains: Capabilities Link Responsibility, Risk (Opportunity), and Performance. International Journal of Production Economics, 140(1), 103-115.

Kohtamäki, M., Partanen, J., \& Möller, K. (2013). Making a profit with R\&D services-The critical role of relational capital. Industrial Marketing Management, 42(1), 71-81.

Kohtamäki, M., Vesalainen, J., Henneberg, S., Naudé, P., \& Ventresca, M. J. (2012). Enabling relationship structures and relationship performance improvement: The moderating role of relational capital. Industrial Marketing Management, 41(8), 1298-1309.

Koplin, J., Seuring, S., \& Mesterharm, M. (2007). Incorporating sustainability into supply management in the automotive industry - the case of the Volkswagen Ag. Journal of Cleaner Production, 15(11-12), 1053-1062.

Kostova, T., \& Roth, K. (2003). "Social capital in multinational corporations and a micro-macro model of its formation." Academy of Management Review 28 (2): 297-317.

Krause, D. R., Handfield, R. B., \& Tyler, B. B. (2007). The relationships between supplier development, commitment, social capital accumulation and performance improvement. Journal of Operations Management, 25(2), 528-545.

Kulangara, N. P., Jackson, S. A., \& Prater, E. (2016). Examining the impact of socialization and information sharing and the mediating effect of trust on innovation capability. International Journal of Operations \& Production Management, 36(11), 1601-1624.

Lawson, B., Tyler, B. B., \& Cousins, P. D. (2008). Antecedents and consequences of social capital on buyer performance improvement. Journal of Operations Management, 26(3), 446-460.

Lee, C. H., \& Ha, B. C. (2018). The impact of buyer-supplier relationships' social capital on bi-directional information sharing in the supply chain. Journal of Business \& Industrial Marketing, 33(3), 325336.

Lee, S. Y. (2016). Responsible supply chain management in the Asian context: the effects on relationship commitment and supplier performance. Asia Pacific Business Review, 22(2), 325342. 
Li, L. Y. (2010). Antecedents of principal-Agent relationship value: The differential impact of social capital and dynamic learning factors. Journal of Marketing Channels, 17(4), 313-338.

Li, Y., Ye, F., \& Sheu, C. (2014). Social capital, information sharing and performance: Evidence from China. International Journal of Operations \& Production Management, 34(11), 1440-1462.

Li, Y., Ye, F., \& Sheu, C. (2014). Social capital, information sharing and performance: Evidence from China. International Journal of Operations \& Production Management, 34(11), 1440-1462.

Liao, K., Sharkey, T. W., Ragu-Nathan, T. S., \& Vonderembse, M. (2012). Trust-driven joint operational activities to achieve mass customization: a culture perspective. Benchmarking: An International Journal, 19(4/5), 585-603.

Lioliou, E., \& Zimmermann, A. (2015). Vendor opportunism in IT outsourcing: a TCE and social capital perspective. Journal of Information Technology, 30(4), 307-324.

Liu, Y., Luo, Y., \& Liu, T. (2009). Governing buyer-supplier relationships through transactional and relational mechanisms: Evidence from China. Journal of Operations Management, 27(4), 294309.

Lu, R. X., Lee, P. K., \& Cheng, T. C. E. (2012). Socially responsible supplier development: Construct development and measurement validation. International Journal of Production Economics, 140(1), 160-167.

Lund-Thomsen, P. (2008). The global sourcing and codes of conduct debate: five myth and five recommendations. Development and Change, 39(6), 1005-1018.

Lund-Thomsen, P., \& Lindgreen, A. (2014). Corporate social responsibility in global value chains: Where are we now and where are we going? Journal of Business Ethics, 123(1), 11-22.

Luo, Y., Liu, Y., Yang, Q., Maksimov, V., \& Hou, J. (2015). Improving performance and reducing cost in buyer-supplier relationships: The role of justice in curtailing opportunism. Journal of Business Research, 68(3), 607-615.

Make UK (2019). UK Manufacturing: 2019/20 The Facts. London, United Kingdom: Author. $\begin{array}{llll}\text { Retrieved } \quad \text { February, } & 13 & 2020 & \text { from }\end{array}$ https://www.makeuk.org/insights/publications/2019/09/13/uk-manufacturing-the-facts2019-20.

Mani, V., \& Gunasekaran, A. (2018). Four forces of supply chain social sustainability adoption in emerging economies. International Journal of Production Economics, 199, 150-161.

Mani, V., Agarwal, R., Gunasekaran, A., Papadopoulos, T., Dubey, R., \& Childe, S. J. (2016). Social sustainability in the supply chain: Construct development and measurement validation. Ecological Indicators, 71, 270-279.

Mani, V., Gunasekaran, A., \& Delgado, C. (2018). Enhancing supply chain performance through supplier social sustainability: An emerging economy perspective. International Journal of Production Economics, 195, 259-272.

Marshall, D., McCarthy, L., Claudy, M., \& McGrath, P. (2017). Piggy in the middle: How direct customer power affects first-tier suppliers' adoption of socially responsible procurement practices and performance. Journal of Business Ethics, 1-22. 
Marshall, D., McCarthy, L., Heavey, C., \& McGrath, P. (2015). Environmental and social supply chain management sustainability practices: construct development and measurement. Production Planning \& Control, 26(8), 673-690.

Misztal, B. (1996). Trust in Modern Societies. Cambridge: Polity Press.

Nahapiet, J., \& Ghoshal, S. (1998). Social capital, intellectual capital, and the organizational advantage. Academy of Management Review, 23(2), 242-266.

$\mathrm{Ni}, \mathrm{W} .$, \& Sun, H. (2018). A contingent perspective on the synergistic effect of governance mechanisms on sustainable supply chain. Supply Chain Management: An International Journal, 23(3), 153170.

Normann, U., Ellegaard, C., \& Møller, M. M. (2017). Supplier perceptions of distributive justice in sustainable apparel sourcing. International Journal of Physical Distribution \& Logistics Management, 47(5), 368-386.

Nunnally, J. (1978). Psychometric Theory. (2ndedn). McGraw-Hill: New York.

Pedersen, E. R., \& Andersen, M. (2006). Safeguarding corporate social responsibility (CSR) in global supply chains: how codes of conduct are managed in buyer-supplier relationships. Journal of Public Affairs: An International Journal, 6(3-4), 228-240.

Peng, D. X., \& Lai, F. (2012). Using partial least squares in operations management research: A practical guideline and summary of past research. Journal of Operations Management, 30(6), 467-480.

Peng, D. X., and Lai, F. (2012). Using partial least squares in operations management research: A practical guideline and summary of past research. Journal of Operations Management, 30(6), 467-480.

Pinheiro, M. L., Serôdio, P., Pinho, J. C., \& Lucas, C. (2016). The role of social capital towards resource sharing in collaborative R\&D projects: Evidences from the 7th Framework Programme. International Journal of Project Management, 34(8), 1519-1536.

Podsakoff, P. M., \& Organ, D. W. (1986). Self-reports in organizational research: Problems and prospects. Journal of Management, 12(4), 531-544.

Podsakoff, P. M., MacKenzie, S. B., Lee, J. Y., \& Podsakoff, N. P. (2003). Common method biases in behavioral research: a critical review of the literature and recommended remedies. Journal of Applied Psychology, 88(5), 879-903.

Poppo, L., \& Zenger, T. (2002). Do formal contracts and relational governance function as substitutes or complements?. Strategic Management Journal, 23(8), 707-725.

Porteous, A. H., Rammohan, S. V., \& Lee, H. L. (2015). Carrots or sticks? Improving social and environmental compliance at suppliers through incentives and penalties. Production and Operations Management, 24(9), 1402-1413.

Porter, M. E. (1980). Competitive Strategy. New York: Free Press.

Qureshi, I., \& Compeau, D. (2009). Assessing between-group differences in information systems research: A comparison of covariance-and component-based SEM. MIS Quarterly, 33(1), 197214. 
Reinartz, W., Haenlein, M., \& Henseler, J. (2009). An empirical comparison of the efficacy of covariance-based and variance-based SEM. International Journal of Research in Marketing, 26(4), 332-344.

Rhodes, C. (2020). Manufacturing: Statistics and Policy. London, United Kingdom: House of Commons Library. Retrieved February, $13 \quad 2020$ from https://researchbriefings.parliament.uk/ResearchBriefing/Summary/SN01942.

Rindfleisch, A., Malter, A. J., Ganesan, S., \& Moorman, C. (2008). Cross-sectional versus longitudinal survey research: Concepts, findings, and guidelines. Journal of Marketing Research, 45(3), 261279.

Roden, S., \& Lawson, B. (2014). Developing social capital in buyer-supplier relationships: The contingent effect of relationship-specific adaptations. International Journal of Production Economics, 151, 89-99.

Rodríguez, J. A., Giménez Thomsen, C., Arenas, D., \& Pagell, M. (2016). NGOs' initiatives to enhance social sustainability in the supply chain: poverty alleviation through supplier development programs. Journal of Supply Chain Management, 52(3), 83-108.

Sancha, C., Gimenez, C., \& Sierra, V. (2016). Achieving a socially responsible supply chain through assessment and collaboration. Journal of Cleaner Production, 112(3), 1934-1947.

Sancha, C., Gimenez, C., Sierra, V., \& Kazeminia, A. (2015). Does implementing social supplier development practices pay off?. Supply Chain Management: An International Journal, 20(4), 389-403.

Son, B. G., Kocabasoglu-Hillmer, C., \& Roden, S. (2016). A dyadic perspective on retailer-supplier relationships through the lens of social capital. International Journal of Production Economics, 178, 120-131.

Tourangeau, R., Rips, L. J., \& Rasinski, K. (2000). The Psychology of Survey Response. Cambridge, England: Cambridge University Press.

Tsai, W., \& Ghoshal, S. (1998). Social capital and value creation: The role of intrafirm networks. Academy of Management Journal, 41(4), 464-476.

Unal, B., \& Donthu, N. (2014). Role of absorptive capabilities in outsourcing the headquarters selling task in the United States. Industrial Marketing Management, 43(6), 1079-1084.

Villena, V. H., Revilla, E., \& Choi, T. Y. (2011). The dark side of buyer-supplier relationships: A social capital perspective. Journal of Operations Management, 29(6)m 561-576.

Voorhees, C. M., Brady, M. K., Calantone, R. \& Ramirez, E. (2016). Discriminant validity testing in marketing: an analysis, causes for concern, and proposed remedies. Journal of the Academy of Marketing Science, 44(1), 119-134.

Walker, H., \& Jones, N. (2012). Sustainable supply chain management across the UK private sector. Supply Chain Management: An International Journal, 17(1), 15-28.

Wang, L., \& Li, J. (2017). The antecedents and innovation outcomes of firms' absorptive capacity in global buyer-supplier relationships. The Journal of Technology Transfer, 42(6), 1407-1430. 
Wang, L., Terziovski, M., Jiang, F., \& Li, J. (2017). The effect of social capital on local suppliers' exploitative and exploratory learning in global buyer-supplier relationships: the moderating role of contract specificity. $R \& D$ Management, 47(4), 654-668.

Wang, Q., Li, J. J., Ross, W. T., \& Craighead, C. W. (2013). The interplay of drivers and deterrents of opportunism in buyer-supplier relationships. Journal of the Academy of Marketing Science, 41(1), 111-131.

Werts, C. E., Linn, R. L., \& Jöreskog, K. G. (1974). Intraclass reliability estimates: Testing structural assumptions. Educational and Psychological Measurement, 34(1), 25-33.

Whipple, J. M., Wiedmer, R., \& K. Boyer, K. (2015). A dyadic investigation of collaborative competence, social capital, and performance in buyer-supplier relationships. Journal of Supply Chain Management, 51(2), 3-21.

Williamson, O.E. (1975). Markets and Hierarchies: Analysis and Antitrust Implications. Free Press: New York.

Wuyts, S., \& Geyskens, I. (2005). The formation of buyer-supplier relationships: detailed contract drafting and close partner selection. Journal of Marketing, 69(4), 103-117.

Yadlapalli, A., Rahman, S., \& Gunasekaran, A. (2018). Socially responsible governance mechanisms for manufacturing firms in apparel supply chains. International Journal of Production Economics, 196, 135-149.

Yawar, S. A., \& Seuring, S. (2018). The role of supplier development in managing social and societal issues in supply chains. Journal of Cleaner Production, 182, 227-237.

Yim, B., \& Leem, B. (2013). The effect of the supply chain social capital. Industrial Management \& Data Systems, 113(3), 324-349.

Yu, X. (2008). Impacts of Corporate Code of Conduct on Labor Standards: A Case Study of Reebok's Athletic Footwear Supplier Factory in China. Journal of Business Ethics, 81(3), 513-529.

Zhang, M., Guo, H., \& Zhao, X. (2017). Effects of social capital on operational performance: impacts of servitisation. International Journal of Production Research, 55(15), 4304-4318.

Zhang, M., Pawar, K. S., \& Bhardwaj, S. (2017). Improving supply chain social responsibility through supplier development. Production Planning \& Control, 28(6-8), 500-511.

Zorzini, M., Hendry, L. C., Huq, F. A., \& Stevenson, M. (2015). Socially responsible sourcing: reviewing the literature and its use of theory. International Journal of Operations \& Production Management, 35(1), 60-109. 
Insert Appendix (1) here 
Table (1): Sample characteristics

\begin{tabular}{lcc}
\hline Position & No. & $\%$ \\
\hline Operations Manager & 27 & 22.7 \\
President/CEO & 24 & 20.2 \\
Procurement manager & 24 & 20.2 \\
Purchasing Manager & 19 & 16.0 \\
Supply Chain Manager & 17 & 14.3 \\
Logistics Manager & 5 & 4.2 \\
Others & 3 & 2.5 \\
Total & 119 & 100 \\
\hline Industry & No. & $\%$ \\
\hline Chemicals, plastics and non-metallic products & 20 & 16.8 \\
Metals and metal products & 17 & 14.3 \\
Automotive and transportation equipment & 15 & 12.6 \\
Electricity, electronics and semiconductor & 14 & 11.8 \\
Machinery and industry equipment & 14 & 11.8 \\
Food, beverages and tobacco & 12 & 10.1 \\
Textiles and apparel & 8 & 6.7 \\
Wood, cork and paper & 6 & 5.0 \\
Furniture & 5 & 4.2 \\
Pharmaceutical & 4 & 3.4 \\
Others & 4 & 3.4 \\
Total & 119 & 100 \\
\hline Supplier-Relationship Length (No. of years) & No. & $\%$ \\
\hline <3 & 12 & 10.1 \\
3 - 6 & 42 & 35.3 \\
7 - 10 & 27 & 22.7 \\
Total & 37 & 31.1 \\
\hline Firm Size (No. of employees) & 119 & 100 \\
\hline 250 - 500 & No. & $\%$ \\
T01 - 1000 & 47 & 37.6 \\
To01- 1500 & 31 & 28.4 \\
\hline & 18 & 16.5 \\
Total & 19 & 17.4 \\
\hline
\end{tabular}

Table (2): Discriminant validity analysis (HTMT method)

\begin{tabular}{|c|l|c|c|c|c|c|c|c|}
\hline \multicolumn{2}{|c|}{ Construct } & A & B & C & D & E & F & G \\
\hline A & Supplier dependency & & & & & & & \\
\hline B & Assessment practices & .130 & & & & & & \\
\hline C & Collaboration practices & .158 & .519 & & & & & \\
\hline D & Relational capital & .179 & .160 & .185 & & & & \\
\hline E & Cognitive capital & .136 & .224 & .211 & .678 & & & \\
\hline F & Structural capital & .179 & .233 & .346 & .774 & .747 & & \\
\hline G & Supplier's social performance & .111 & .475 & .597 & .299 & .311 & .415 & \\
\hline
\end{tabular}


Table (3): Results of the structural model

\begin{tabular}{|c|c|c|c|c|c|c|}
\hline \multirow{4}{*}{ Construct } & \multicolumn{4}{|c|}{ Direct effects models } & \multirow{2}{*}{\multicolumn{2}{|c|}{$\frac{\text { Interaction effects model }}{\text { Model } 3}$}} \\
\hline & \multicolumn{2}{|c|}{ Model 1} & \multicolumn{2}{|c|}{ Model 2} & & \\
\hline & \multicolumn{2}{|c|}{$\begin{array}{l}\text { Supplier's social } \\
\text { performance }\end{array}$} & \multicolumn{2}{|c|}{$\begin{array}{l}\text { Supplier's social } \\
\text { performance }\end{array}$} & \multicolumn{2}{|c|}{$\begin{array}{l}\text { Supplier's social } \\
\text { performance }\end{array}$} \\
\hline & $B$ & $\mathrm{t}$ & $b$ & $t$-value & b & $t$-value \\
\hline Relationship length & 0.08 & 0.53 & 0.04 & 0.46 & 0.01 & 0.12 \\
\hline Supplier dependency & 0.16 & 0.72 & 0.09 & 0.57 & 0.04 & 0.317 \\
\hline Assess. practices & & & 0.11 & 0.97 & 0.10 & .95 \\
\hline Collab. practices & & & 0.21 & $3.14^{* * *}$ & 0.22 & $3.03^{* *}$ \\
\hline Relational capital & & & 0.12 & 1.16 & 0.094 & 0.89 \\
\hline Cognitive capital & & & 0.10 & 1.02 & 0.09 & 1.10 \\
\hline Structural capital & & & 0.15 & 1.32 & 0.19 & $1.90^{*}$ \\
\hline Assess. $\mathrm{x}$ relational capital & & & & & 0.28 & $2.72^{* *}$ \\
\hline Collab. x relational capital & & & & & 0.35 & $3.84^{* * *}$ \\
\hline Assess. $x$ cognitive capital & & & & & 0.11 & 0.87 \\
\hline Collab. $x$ cognitive capital & & & & & 0.23 & $2.01^{* *}$ \\
\hline Assess. x structural capital & & & & & 0.27 & $3.30^{* *}$ \\
\hline Collab. $x$ structural capital & & & & & 0.13 & 1.07 \\
\hline $\mathbf{R}^{2}$ & \multicolumn{2}{|c|}{0.019} & \multicolumn{2}{|c|}{0.34} & \multicolumn{2}{|c|}{0.467} \\
\hline$\Delta R^{2}$ & & & \multicolumn{2}{|c|}{0.321} & \multicolumn{2}{|c|}{0.12} \\
\hline
\end{tabular}

$* \mathrm{P} \leq 0.10,{ }^{* *} \mathrm{p} \leq 0.05,{ }^{* * *} \mathrm{p} \leq 0.01$ 
Appendix 1. Measurement items and reliability and validity test

\begin{tabular}{|c|c|}
\hline Items & $\begin{array}{l}\text { Standardised } \\
\text { loadings }\end{array}$ \\
\hline \multicolumn{2}{|l|}{ Assessment practices $C . R .=0.86$ AVE $=0.61$} \\
\hline We developed an ethical code of conduct with our key supplier. & 0.682 \\
\hline We conduct audits of the health and safety of our supplier's employees. & 0.768 \\
\hline $\begin{array}{l}\text { We sent health and safety questionnaires to our supplier in order to monitor their } \\
\text { compliance. }\end{array}$ & 0.704 \\
\hline $\begin{array}{l}\text { We use a certification programme (e.g. SA8000) to recognise the supplier's corporate social } \\
\text { responsibility capability. }\end{array}$ & 0.667 \\
\hline $\begin{array}{l}\text { We assess supplier's social performance through form evaluation using established } \\
\text { guidelines and procedures. }\end{array}$ & 0.848 \\
\hline $\begin{array}{l}\text { We provide our supplier with feedback about the results of such evaluation. } \\
\text { Collaboration practices C. } R .=0.81 \mathrm{AVE}=0.52\end{array}$ & 0.821 \\
\hline $\begin{array}{l}\text { We offer financial incentives for the supplier if they improve commitment to social } \\
\text { sustainability. }\end{array}$ & 0.613 \\
\hline We visit our supplier' facilities to help them improve their performance. & 0.767 \\
\hline $\begin{array}{l}\text { We provide training/education for the supplier's personnel about corporate social } \\
\text { responsibility practices and the required skills. }\end{array}$ & 0.792 \\
\hline $\begin{array}{l}\text { We developed new product/processes with our supplier that reduced health and safety } \\
\text { hazards for employees. }\end{array}$ & 0.721 \\
\hline \multicolumn{2}{|l|}{ Relational capital C.R. $=0.88$ AVE $=0.61$} \\
\hline The relationship is characterized by close interaction at multiple levels & 0.732 \\
\hline The relationship is characterized by mutual trust at multiple levels & 0.853 \\
\hline The relationship is characterized by mutual respect at multiple levels & 0.739 \\
\hline The relationship is characterized by mutual friendship at multiple levels & 0.752 \\
\hline The relationship is characterized by high levels of reciprocity & 0.838 \\
\hline \multicolumn{2}{|l|}{ Cognitive capital C.R. $=0.91$ AVE $=0.73$} \\
\hline We have similar organisational culture /values and management style with supplier & 0.864 \\
\hline We have similar philosophies/approaches to business dealings & 0.847 \\
\hline We have compatible goals and objectives with suppliers. & 0.828 \\
\hline We have the same vision of business in the relationships & 0.928 \\
\hline \multicolumn{2}{|l|}{ Structural capital C. $R .=0.86$ AVE $=0.61$} \\
\hline We engage in and organise social events with our suppliers & 0.774 \\
\hline We have frequent communication with our major supplier & 0.669 \\
\hline We maintain a frequent and intensive interaction between personnel & 0.849 \\
\hline We maintain close social relationships with our major suppliers & 0.822 \\
\hline \multicolumn{2}{|l|}{ Supplier's social performance C.R. $=0.93$ AVE $=0.83$} \\
\hline We have improved compliance with human rights in the supplier' facilities. & 0.934 \\
\hline We have improved safety and labour conditions in the supplier' facilities. & 0.938 \\
\hline $\begin{array}{l}\text { We have improved compliance with child labour employment in the supplier' facilities. } \\
\text { Supplier's dependency C.R. }=0.60 \mathrm{AVE}=0.85\end{array}$ & 0.856 \\
\hline $\begin{array}{l}\text { If we discontinued our relationship, it would have difficult for this supplier to make up the } \\
\text { sales volume in our trading area. }\end{array}$ & 0.67 \\
\hline It would be difficult for this supplier to replace us. & 0.66 \\
\hline This supplier is quite dependent on us. & 0.95 \\
\hline This supplier does not have a good alternative to us in our trading area. & 0.77 \\
\hline
\end{tabular}




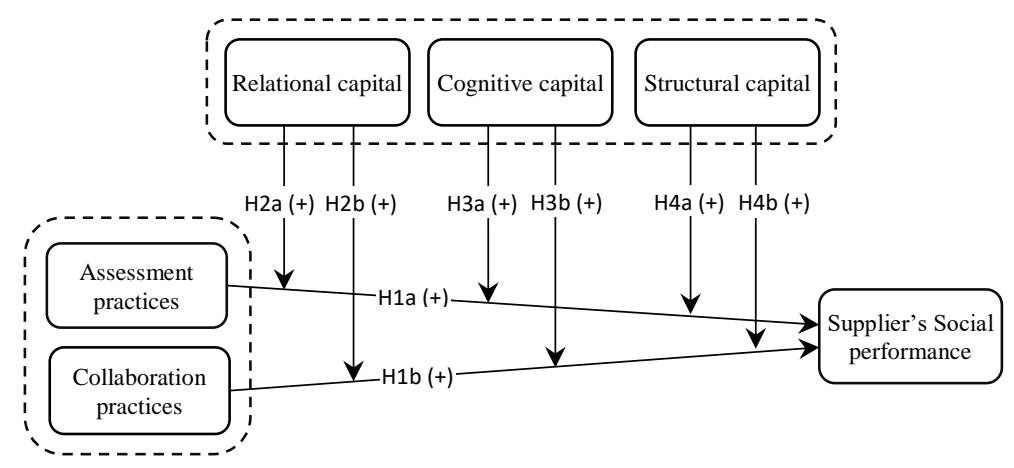

Figure (1): Conceptual model 